\title{
Structure and Properties of Vacuum Arc Single-Layer and Multiperiod Two-Layer Nitride Coatings Based on Ti(Al):Si Layers
}

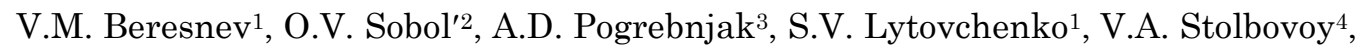
P.A. Srebniuk ${ }^{1}$, V.Ju. Novikov ${ }^{5}$, I.V. Doshchechkina ${ }^{6}$, A.A. Meylehov², A.A. Postelnyk ${ }^{2}$, U.S. Nyemchenko ${ }^{1}$, B.A. Mazylin ${ }^{1}$, V.V. Kruhlova ${ }^{1}$

1 V.N. Karazin Kharkiv National University, 4, Svoboby Sq., 61000 Kharkiv, Ukraine 2 National Technical University "Kharkiv Polytechnic Institute”, 2, Kyrpychov St., 61000 Kharkiv, Ukraine

3 Sumy State University, 2, Rymskyi-Korsakov St., 40007 Sumy, Ukraine

${ }^{4}$ National Scientific Centre "Kharkiv Institute of Physics and Technology", 1, Akademichna St., 61108 Kharkiv Ukraine

5 Belgorod National Research University, 85, Pobedy St., 308015 Belgorod, Russia

${ }^{6}$ Kharkiv National Automobile and Highway University, 25, Ya. Mudryi St., 61200 Kharkiv, Ukraine

(Received 06 December 2016; revised manuscript received 17 February 2017; published online 20 February 2017)

\begin{abstract}
The paper provides an analysis of impact of deposition conditions on structural and phase state and thermal stability of vacuum arc coatings based on Ti(Al):Si layers. We studied single-phase single-layer coatings, and multiperiod bilayer coatings with second phase nitride interlayers of one of the following three metals: $\mathrm{Mo}, \mathrm{Cr}$ or Zr. It was established that hexagonal and cubic lattices may form in the coatings when transition to the cubic lattice occurs with $\mathrm{Al}$ content of about 25 at. \%. Presence of second nanoscale $(7-8 \mathrm{~nm})$ layers in bilayer multiperiod compositions, which consist of one nitride from $\mathrm{CrN}_{x}, \mathrm{MoN}_{x}$ or $\mathrm{ZrN}_{x}$ group, does not change the type of lattice in [Ti(Al):Si] $\mathrm{N}_{x}$ layers. Also, an $f c c$ lattice with a strong or weak texture [111] forms in $\mathrm{CrN}_{x}$ and $\mathrm{ZrN}_{x}$ layers, while crystallites with hexagonal lattice form in $\mathrm{MoN}_{x}$ layers. High-temperature annealing at $700{ }^{\circ} \mathrm{C}$ during 40 minutes leads to a significant (by $23 \%$ or up to $H_{\mu}=47.56 \mathrm{GPa}$ ) increase in microhardness of coating of the $[\mathrm{Ti}(\mathrm{Al})] \mathrm{N}_{x} / \mathrm{ZrN}_{y}$ system due to formation of a nano-size structure with an average size of crystallites of $3.6 \mathrm{~nm}$ in [Ti(Al)] $\mathrm{N}_{x}$ layers, and $6.3 \mathrm{~nm}$ in $\mathrm{ZrN}_{x}$ layers.
\end{abstract}

Keywords: Nitride coatings, Multilayers coating, Composition of elements, Structure, Microhardness.

DOI: 10.21272/jnep.9(1).01033

PACS numbers: 61.46. - w, 62.20.Qp, 62-65. - g

\section{INTRODUCTION}

The growing interest to high-temperature coatings has predetermined an intensive development of technology of formation of composite multielement multilayer coatings, in which high functional properties are obtained through correct choice of constituent ingredients [1-2]. The right structural condition, which is obtained through structural engineering techniques [3] under development, is another factor to ensure required properties of the material.

Nitride coatings based on $\mathrm{TiN}_{x}$ have high mechanical properties but comparatively low thermal stability $[4,5]$. Their mechanical and tribological characteristics, as well as thermal stability and resistance to oxidation can be significantly improved by adding aluminum. Depending on the composition of elements, materials of the triple system based on $\mathrm{Al}$, Ti and $\mathrm{N}$ can have either cubic or hexagonal structure. The $[\mathrm{Al}(\mathrm{Ti})] \mathrm{N}_{x}$ metastable solid-state solution with the cubic face-centered $(f c c)$ $\mathrm{NaCl}$ structure (B1 type) keeps stable up to $x=0.6-0.8$ [6]. With the amount of titan exceeding the said upper limit, a crystal hexagonal lattice of $\mathrm{ZnS}$ type (wurtzite) forms. The coatings based on $\mathrm{Al}$, Ti and N, unlike their analogues with $f c c$ structure, have comparatively high thermal stability, but at temperatures higher than $900{ }^{\circ} \mathrm{C}$ they lose most of their mechanical properties and resistance to oxidation [7].

Silicon additives significantly change the structural and phase state, stereological characteristics and physical-chemical properties of nitride coatings, particularly, we observe increase in hardness and stability to oxidation of nitride layers [8]. Segregation of silicon atoms on grain boundaries leads to formation of amorphous-like $\mathrm{SiN}_{x}$ phase, the interlayers of which segregate titan nitride or aluminum nitride grains and in such a way prevent their growth [9]. Such nanocomposite can have unique mechanical properties and thermal stability, and therefore it is a very promising material for high-temperature [10-12].

Another technique facilitating formation of the nano-structural state and therefore improving performance of the coating is creation of multilayer systems with a nanosized interlayer period. We believe that nitrides of transitional metals are promising materials for application in formation of the said structures.

The objective of this work was to carry out a feasibility study of structural engineering to improve hightemperature hardness of TiAl-based initial coatings by forming various nitride layers and multiperiod compositions based on them. In the course of this study, as a second layer in multiperiod systems, we formed three different nitrides with different enthalpies of formation: $\mathrm{ZrN}_{x} \quad(-365 \mathrm{~kJ} / \mathrm{mol}), \quad \mathrm{CrN}_{x} \quad(-123.4 \mathrm{~kJ} / \mathrm{mol}), \quad \mathrm{MoN}_{x} \quad(-$ $37 \mathrm{~kJ} / \mathrm{mol})$.

\section{SPECIMENS AND METHODS OF STUDY}

We obtained coatings by vacuum-arc technique using an upgraded modification of Bulat- 6 unit [13]. The working (ammonium) pressure in deposition (P) was $1 \times 10^{-5}$ or $4 \times 10^{-3}$ Torr. The deposition was carried out from one $\mathrm{Ti}(\mathrm{Al}): \mathrm{Si}$ composition or two sources. When two sources were used, the composition of the first one was just like in 
the former case, i.e. Ti(Al):Si, while the second source was metallic. We applied one of the following three metals in various options: either $\mathrm{Mo}$, or $\mathrm{Cr}$, or $\mathrm{Zr}$.

The coatings were deposited on $15 \times 15 \mathrm{~mm}^{2}$ specimen plates which were $2.5 \mathrm{~mm}$ thick and made of $\mathrm{X} 18 \mathrm{H} 10 \mathrm{~T}$ stainless steel.

In coating formation from two sources, specimens were fixed on a special platform which was constantly rotating during deposition shifting the specimens from

Table 1 - Modes of coating formation one source to the other. With the rotation speed of $8 \mathrm{rpm}$, it took 1 hour to form a $9 \mu \mathrm{m}$ thick coating. This coating consisted of $7-8 \mathrm{~nm}$ thick biphasic interlayers. In the process of deposition, the substrates were kept at a constant negative potential $U_{s p}$ of 50 or $100 \mathrm{~V}$. The specific modes of deposition are shown in Table $1\left(I_{a}-\right.$ arc current of the first and second cathode source, $I_{f}-$ focusing current, $U_{s p}$ - potential on the substrate during deposition, $P$ - pressure of nitrogen atmosphere).

\begin{tabular}{|c|c|c|c|c|c|}
\hline Series No & Cathode(s) & $I_{a}, \mathrm{~A}$ & $I_{f}, \mathrm{~A}$ & $U_{s p}, \mathrm{~V}$ & $P$, Torr \\
\hline 1 & $\mathrm{Ti}(\mathrm{Al}): \mathrm{Si}$ & 100 & 0,5 & -50 & $1 \times 10^{-5}$ \\
\hline 2 & $\mathrm{Ti}(\mathrm{Al}): \mathrm{Si}$ & 100 & 0,5 & -110 & $4 \times 10^{-3}$ \\
\hline 3 & $\begin{array}{c}\mathrm{Ti}(\mathrm{Al}): \mathrm{Si} \\
\mathrm{Cr}\end{array}$ & $\begin{array}{c}100 \\
90\end{array}$ & $\begin{array}{l}0,5 \\
0,4\end{array}$ & -110 & $4 \times 10^{-3}$ \\
\hline 4 & $\begin{array}{l}\mathrm{Ti}(\mathrm{Al}): \mathrm{Si} \\
\text { Mo }\end{array}$ & $\begin{array}{l}100 \\
150\end{array}$ & $\begin{array}{l}0,5 \\
0,4\end{array}$ & -110 & $4 \times 10^{-3}$ \\
\hline 5 & $\begin{array}{c}\mathrm{Ti}(\mathrm{Al}): \mathrm{Si} \\
\mathrm{Zr}\end{array}$ & $\begin{array}{c}100 \\
90\end{array}$ & $\begin{array}{l}0,5 \\
0,4\end{array}$ & -110 & $4 \times 10^{-3}$ \\
\hline
\end{tabular}

After deposition, the composites were annealed at $700{ }^{\circ} \mathrm{C}$ during 40 minutes in a VHT 8/22-GR Nabertherm $\mathrm{GmbH}$ vacuum furnace at a residual pressure of no more than $3 \times 10^{-5}$ Torr.

The structure and phase analysis of obtained coatings was done by X-ray diffraction method in a radiation of $\mathrm{Cu}-k a$ using a DRON-4 diffractometer. The profiles were separated with the help of the New Profile software package. To analyze the profiles, we used the New Profile software package.

The microhardness was measured by an AFFRI DM-8 using standard methods under an applied load of $50 \mathrm{~g}$ on the indentor.

The elemental composition was determined by energy dispersive spectra obtained on an EDAX X-ray microanalizer, which was combined with a Quanta 200 3D scanning electron and ion microscope.

\section{RESULTS AND THEIR DISCUSSION}

The phase composition, structure and mechanical properties of [ $\mathrm{Ti}(\mathrm{Al}): \mathrm{Si}] \mathrm{N}_{x}$ coatings can be efficiently controlled by setting appropriate deposition parameters. Particularly, change of energy in falling particles substantially influences the mechanism of film growth and hence its properties. The process of vacuum arc evaporation provides highly ionized plasma with ions of metals which are in different states of ionization. Different ion charge states are characterized by different energy of particles, which may increase the impact energy of ions when they hit substrates. Such an increase of energy may be achieved without growth of bias voltage on the substrate. Besides, high energy of falling ions leads to thickening of coatings. Thus, with relatively insignificant bias voltages, we can form coatings with a dense structure and comparatively low porosity.

The electronic microscopy data (Fig. 1) show that [Ti(Al):Si] $\mathrm{N}_{x}$-based coatings have a dense and practically droplet-free structure, whose homogeneity increases during annealing.

The elemental analysis of coatings was carried out on energy dispersive spectra which have a typical look in $[\mathrm{Ti}(\mathrm{Al})] \mathrm{N}_{x} / \mathrm{ZrN}_{y}$ systems (Table 1, Series 5) as shown in Fig. 2.
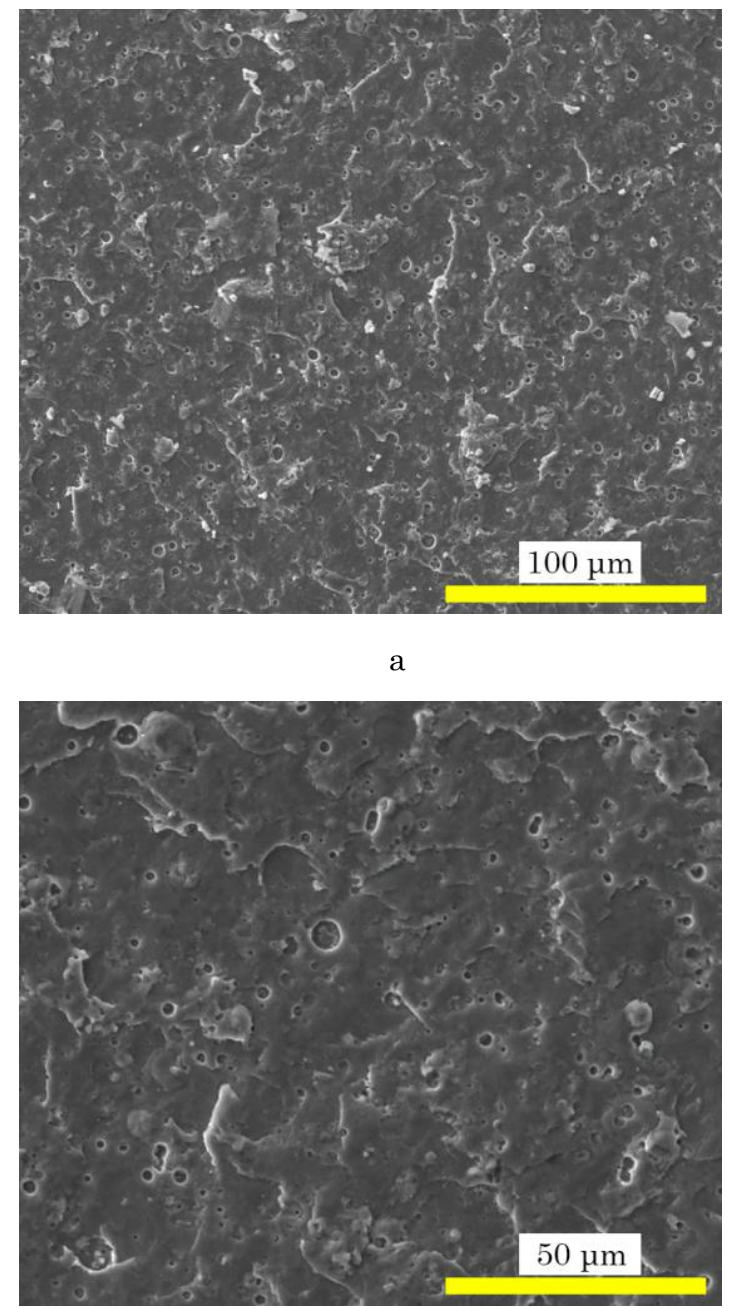

$\mathrm{b}$

Fig. 1 - Surface of [Ti(Al):Si] $\mathrm{N}_{x}$ coatings before (a) and after (b) annealing

The resulting data of the elemental analysis are provided in Table 2 . It should be noted that the table shows metal atoms content in coatings excluding nitrogen atoms content which does not exceed 2 at. \% for Series 1 
specimens, while it is close to equiatomic contents for specimens of other series (one nitrogen atom per one metal atom).

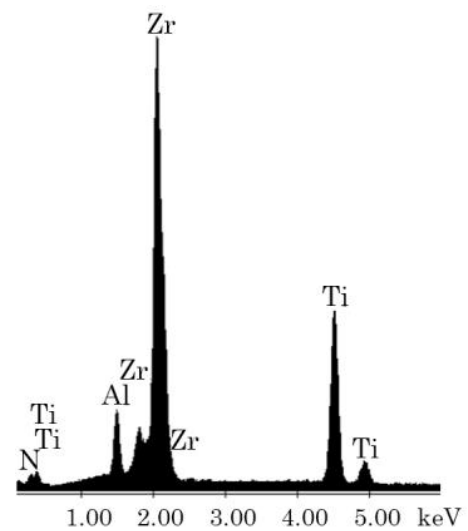

Fig. 2 - Energy dispersive spectra of Series 5 coatings, composition of $[\mathrm{Ti}(\mathrm{Al})] \mathrm{N}_{x} / \mathrm{ZrN}_{y}$

Table 2 shows that in the specimens obtained at low $\left(1 \times 10^{-5}\right.$ Torr) pressure of nitrogen (Series 1 , Table 1$)$ and its small (less than 2 at. \%) content in the coating, the atomic ratio $\mathrm{Ti} / \mathrm{Al}$ makes 3.36 , which corresponds to the content of $\mathrm{Al}$ in the coating in the amount of about 23 at. $\%$.

The increase of nitrogen pressure in deposition up to $4 \times 10^{-3}$ Torr leads to change of Ti/Al ratio towards increased content of $\mathrm{Al}$, which corresponds with its content in the coating totaling about 26.5 at. $\%$.

It is believed that almost all evaporated particles spontaneously interact with dissociated nitrogen forming nitride molecules $\mathrm{Me}-\mathrm{N}(\mathrm{Me}=\mathrm{Al}$, Ti) on the film surface [13]. These molecules (unlike weakly bound metal molecules) are much less subject to repeated sputtering even in relatively intense high-energy ion bombardment. Therefore the suggested cause for change of the Ti/Al ratio in the coating may be preferential formation of stable nitride complexes with $\mathrm{Al}$ in the plasma between the cathode and substrate. Compared to TiN, such formations are more resistant to secondary sputtering from the formed coating surface [14].

Table 2 - Elemental composition and microhardness $\left(H_{\mu}\right)$ of specimens (series as shown in Table 1) before (a) and after (b) annealing

\begin{tabular}{|c|c|c|c|c|c|c|c|c|c|}
\hline \multicolumn{2}{|c|}{ Series No } & \multicolumn{6}{|c|}{ Content of Elements, At.\% } & \multirow{2}{*}{$\mathrm{Ti} / \mathrm{Al}$} & \multirow[t]{2}{*}{$H_{\mu}, \mathrm{GPa}$} \\
\hline & & $\mathrm{Ti}$ & $\mathrm{Al}$ & $\mathrm{Si}$ & $\mathrm{Cr}$ & Mo & $\mathrm{Zr}$ & & \\
\hline \multirow[t]{2}{*}{1} & $\mathrm{a}$ & 74,09 & 23,27 & 2,64 & - & - & - & 3,36 & 6,65 \\
\hline & $\mathrm{b}$ & 74,04 & 23,17 & 2,79 & & & & 3,38 & 9,57 \\
\hline \multirow[t]{2}{*}{2} & $\mathrm{a}$ & 71,89 & 26,23 & 1,90 & - & - & - & 2,74 & 10,58 \\
\hline & $\mathrm{b}$ & 70,78 & 26,50 & 1,85 & & & & 2,67 & 9,85 \\
\hline \multirow[t]{2}{*}{3} & $\mathrm{a}$ & 44,10 & 15,29 & 1,27 & 39,25 & - & - & 2,88 & 27,25 \\
\hline & $\mathrm{b}$ & 43,47 & 15,80 & 1,53 & 39,01 & & & 2,75 & 24,26 \\
\hline \multirow[t]{2}{*}{4} & $\mathrm{a}$ & 34,63 & 10,53 & 0,79 & - & 54,96 & - & 3,28 & 37,46 \\
\hline & $\mathrm{b}$ & 33,30 & 10,74 & 1,11 & & 54,81 & & 3,10 & 37,74 \\
\hline \multirow[t]{2}{*}{5} & $\mathrm{a}$ & 39,67 & 12,20 & - & - & - & 47,80 & 3,25 & 37,90 \\
\hline & $\mathrm{b}$ & 39,40 & 12,10 & & & & 48,50 & 3,28 & 47,56 \\
\hline
\end{tabular}

In case of multilayer systems with coating applied during rotation of the substrate between two sources, the $\mathrm{Ti} / \mathrm{Al}$ ratio changes towards the primer (i.e. towards $\mathrm{Ti} / \mathrm{Al}$ ratio $\approx 3.36$ ). This may be caused by radiation effect of heavy accelerated charged metal particles, the depth of effect of which is comparable to the thickness of layers.

The X-ray research of the structure and phase state of specimens (Fig. 3) has shown that Series 1 coatings (Fig. 3a) are basically a one-phase solid-state solution based on hcp lattice. High-temperature annealing does not lead to a change of the lattice type but stimulates preferred orientation of crystallites with texture plane (101). This conclusion is based on the relative increase of reflection intensity (101) on spectrum curve 2 (Fig. 3a).

Coating deposition with an increased pressure of nitrogen leads to a change of the type of the formed crystal lattice from $h c p$ (Series 1 metal coating) to fcc (Series 2 nitride coating), while the preferred orientation changes from (101) to (111) (Fig. 3b). Annealing does not basically alter the structural state, but leads to relaxation of condensing compressive stresses. On the diffraction spectra, this develops in a proportional spike displacement towards the high-angle region (projection in geometry $\theta-2 \theta$ ).

In multilayer coatings with interlayers $7-8 \mathrm{~nm}$ thick, the $f c c$ lattice ( $\mathrm{NaCl}$ structural type) is formed in two phases of making the coating layer in $[\mathrm{Ti}(\mathrm{Al}): \mathrm{Si}] \mathrm{N}_{x} / \mathrm{CrN}_{y}$ and $[\mathrm{Ti}(\mathrm{Al})] \mathrm{N}_{x} / \mathrm{ZrN}_{y}$ systems. It should be noted that in case of the [Ti(Al):Si] $\mathrm{N}_{x} / \mathrm{CrN}_{y}$ system, the coating has strong preferred orientation of crystallites on planes unchanged (111) (Fig. 3c), while for the [Ti(Al)] $\mathrm{N}_{x} / \mathrm{ZrN}_{y}$ system, preferred orientation is practically not observed (Fig. 3e).

In the $[\mathrm{Ti}(\mathrm{Al}): \mathrm{Si}] \mathrm{N}_{x} / \mathrm{MoN}_{y}$ system in [Ti(Al): $\left.\mathrm{Si}\right] \mathrm{N}_{x}$ layers, preferred orientation changes for axial texture

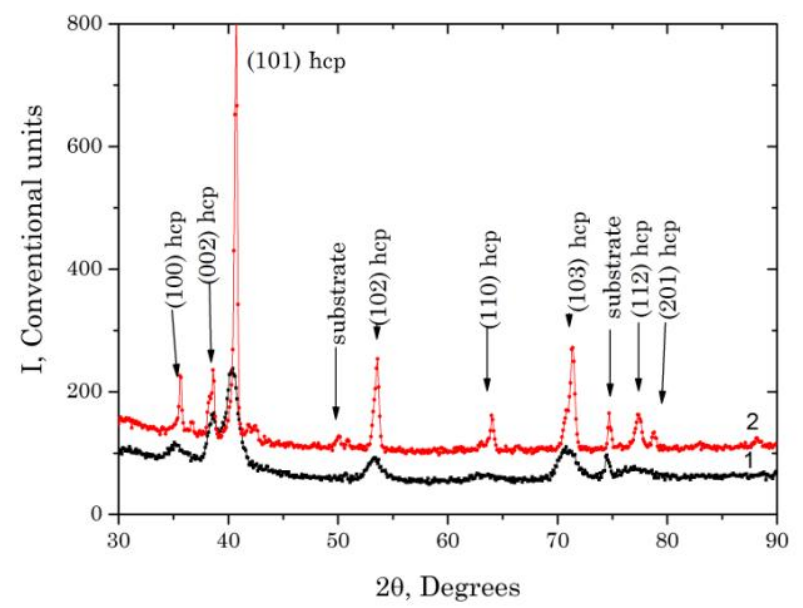




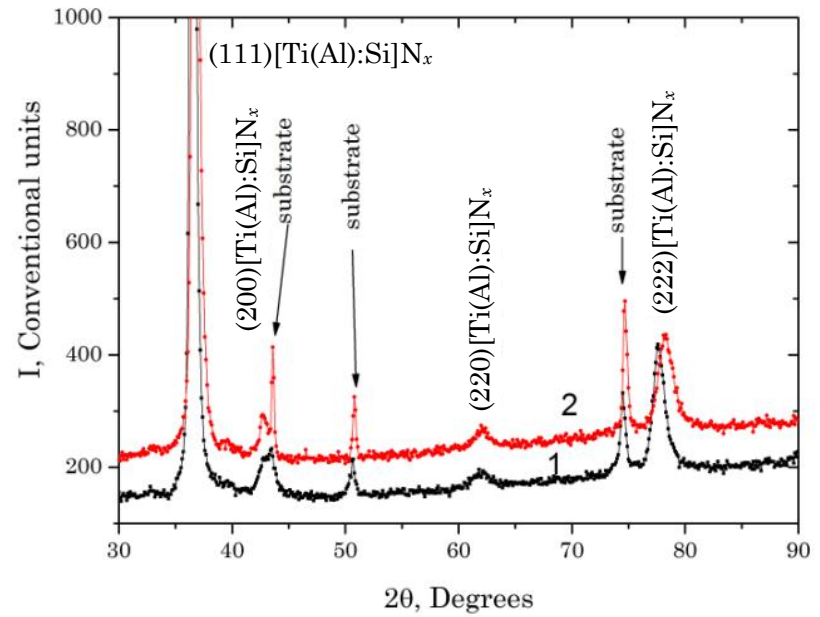

$\mathrm{b}$

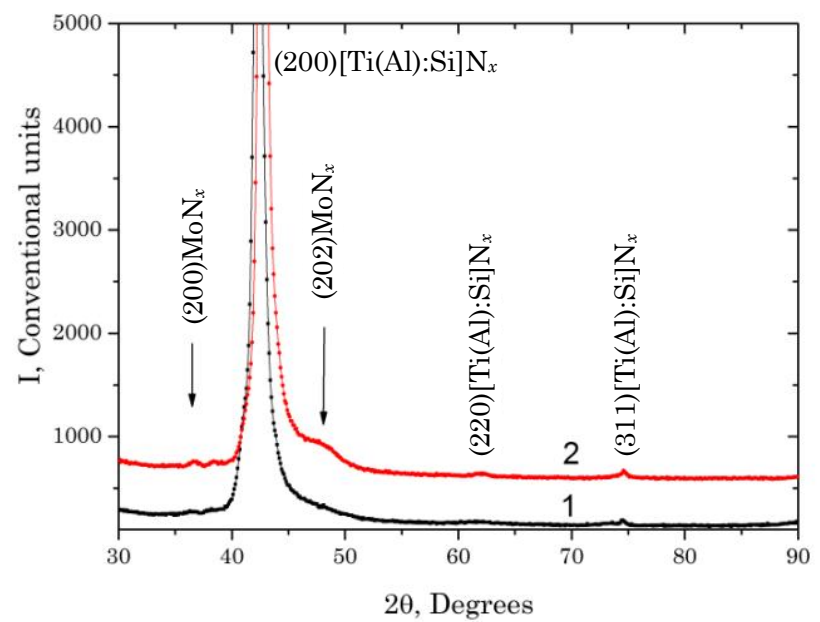

d

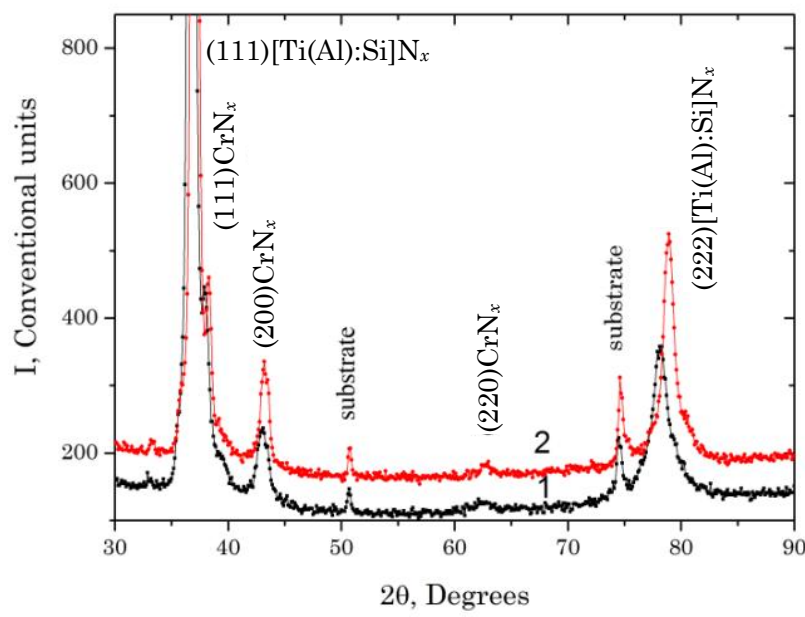

$\mathrm{c}$

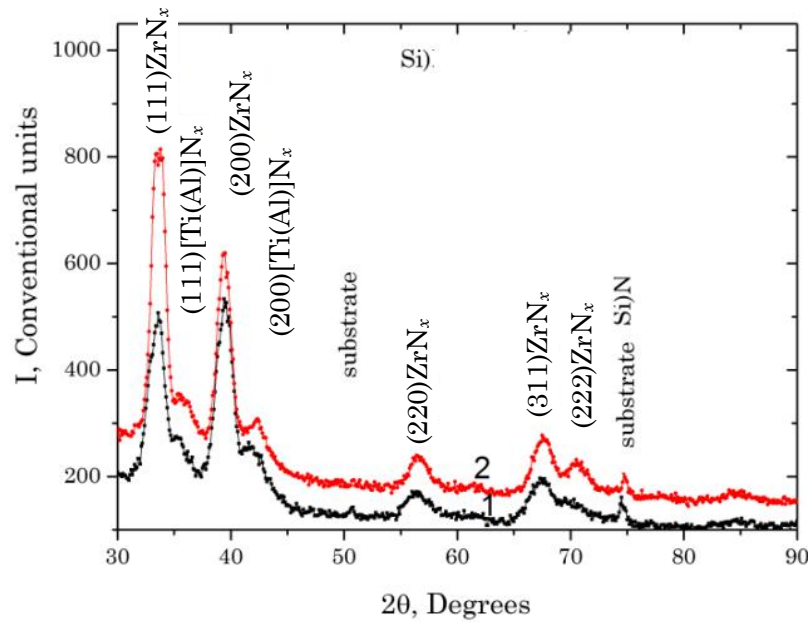

e

Fig. 3 - Areas of diffraction spectra of coatings before (1) and after (2) annealing of specimens of Series: a $-1, b-2, c-3$, $\mathrm{d}-4, \mathrm{e}-5$ at $700^{\circ} \mathrm{C}$ during $40 \mathrm{~min}$

with axis [100] (Fig. 3d), Spectrum 1), while in $\mathrm{MoN}_{x}$ layers, formation of a phase with a hexagonal elementary cell ( $\mathrm{P} 6_{3} / \mathrm{mmc}$ space group) takes place. Annealing does not alter the phase composition in layers of all studied systems, however it leads to relaxation of growth compressive stresses, which shows up in displacement of diffraction reflections on spectra towards the high-angle region (Spectra 1 and 2 in Fig. 1c, d, e).

We have made comparison of the obtained data on elemental composition and structural characteristics with the measurement data on coatings microhardness.

The observed increase of microhardness after annealing (Table 2, Series 5, 6) can be explained by strong texturing with preferred orientation of crystallite planes (101) parallel to the surface.

In $[\mathrm{Ti}(\mathrm{Al}): \mathrm{Si}] \mathrm{N}_{x}$ coatings, as well as in the [Ti(Al):Si] $\mathrm{N}_{x} / \mathrm{CrN}_{y}$ multilayer system, annealing is accompanied by some decrease of hardness owing to relaxation of the initial compressive stresses. In the stronger bound [ $\mathrm{Ti}(\mathrm{Al}): \mathrm{Si}] \mathrm{N}_{x} / \mathrm{MoN}_{y}$ system, annealing at $700{ }^{\circ} \mathrm{C}$ does not practically change coating hardness (Series 4 in Table 2).
A quite significant increase of hardness after annealing (about $23 \%$ ) was observed for the [Ti(Al)] $\mathrm{N}_{x} / \mathrm{ZrN}_{y}$ system. The detailed analysis of X-ray data with separation of components of complex spectra (Fig. 4) showed that annealing leads to practically no relaxation of the initial compression strain in this material. Displacement of diffraction peaks is not observed (Table 3), but their

Table 3 - Parameters of specimen diffraction peaks before (a) and after (b) annealing

\begin{tabular}{|c|c|c|c|c|}
\hline \multicolumn{2}{|c|}{ Peak } & $\begin{array}{c}\text { Position, } \\
2 \theta, \text { Degrees }\end{array}$ & $\begin{array}{c}\text { Intensity, } \\
\text { Relative } \\
\text { Units }\end{array}$ & $\begin{array}{c}\text { Integral } \\
\text { Breadth, } \\
\text { Degrees }\end{array}$ \\
\hline$(111)$ & $\mathrm{a}$ & 33,496 & 311,8 & 1,81 \\
\cline { 2 - 5 } $\mathrm{ZrN}_{x}$ & $\mathrm{~b}$ & 33,643 & 578,7 & 1,51 \\
\hline$(200)$ & $\mathrm{a}$ & 39,413 & 351,0 & 2,00 \\
\cline { 2 - 5 } $\mathrm{ZrN}_{x}$ & $\mathrm{~b}$ & 39,413 & 378,5 & 1,58 \\
\hline$(111)$ & $\mathrm{a}$ & 35,909 & 50,9 & 2,57 \\
\cline { 2 - 5 }$\left[\mathrm{Ti}(\mathrm{Al}) \mathrm{N}_{x}\right.$ & $\mathrm{b}$ & 36,071 & 95,1 & 2,17 \\
\hline$(200)$ & $\mathrm{a}$ & 42,014 & 93,0 & 2,74 \\
\cline { 2 - 5 }$[\mathrm{Ti}(\mathrm{Al})] \mathrm{N}_{x}$ & $\mathrm{~b}$ & 42,205 & 81,7 & 2,54 \\
\hline
\end{tabular}




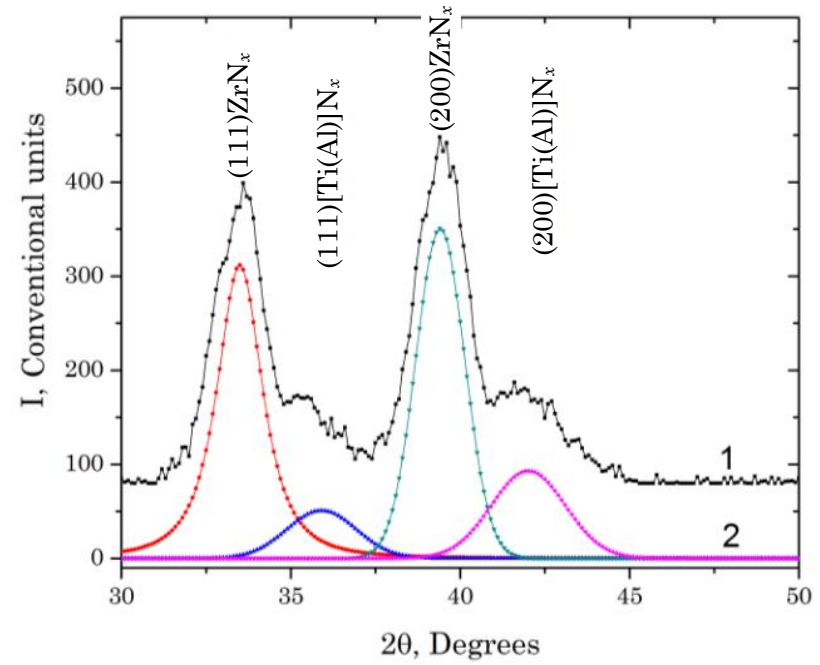

a

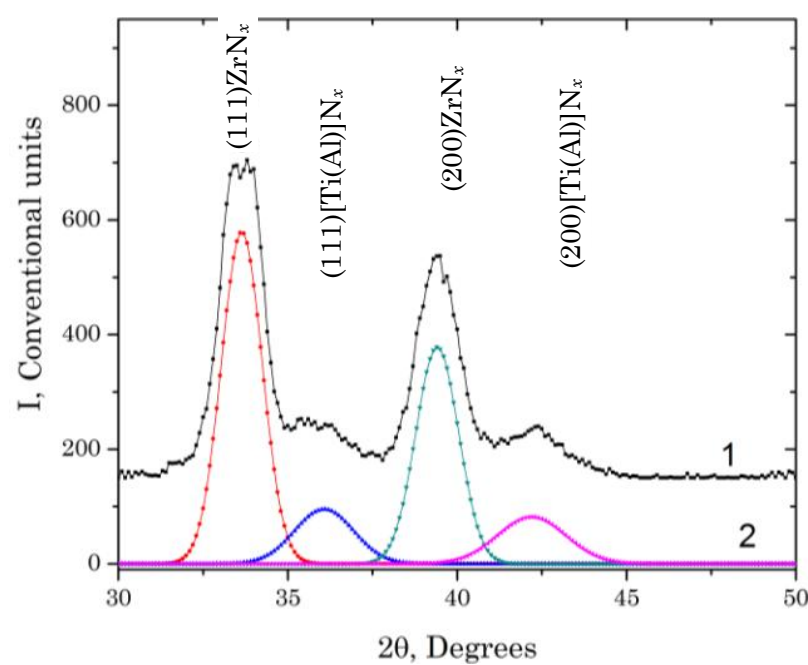

$\mathrm{b}$

Fig. 4 - Areas of diffraction spectra of the [Ti(Al)] $\mathrm{N}_{x} / \mathrm{ZrN}_{y}$ coating before (a) and after (b) annealing: 1 - initial spectrum, 2 - result of profiles separation into components

breadth changes considerably, which is the evidence of changes in the dislocation structure.

Average sizes of crystallites have been estimated by broadening of diffraction reflections using the SelyakovScherrer relation. It has been found that in $[\mathrm{Ti}(\mathrm{Al})] \mathrm{N}_{x}$ layers, as a result of annealing, the average size of crys- tallites changes from 3.4 to $3.8 \mathrm{~nm}$, and in $\mathrm{ZrN}_{x}$ layers from 5.2 to $6.3 \mathrm{~nm}$. Such a change of the average size of crystallites in a nanometer range leads to a transition from rotational strain to shearing strain [15], which eventually defines the observed increase of material hardness.

\section{Структура и свойства вакуумно-дуговых однослойных и многопериодных двухслойных нитридных покрытий на основе слоев $\mathrm{Ti}(\mathrm{Al}): \mathrm{Si}$}

В.М. Береснев ${ }^{1}$, О.В. Соболь ${ }^{2}$ А.Д. Погребняк ${ }^{3}$, С.В. Литовченко ${ }^{1}$, В.А. Столбовой ${ }^{4}$ П.А. Сребнюк ${ }^{1}$, В.Ю. Новиков ${ }^{5}$, И.В. Дощечкина ${ }^{6}$, А.А. Мейлехов ${ }^{2}$, А.А. Постельник ${ }^{2}$, У.С. Немченко ${ }^{1}$, Б.А. Мазылин ${ }^{1}$, В.В. Круглова ${ }^{1}$

${ }^{1}$ Харьковский национальный университет илени В.Н. Каразина, пл. Свободь, 4, 61000 Харьков, Украина

2 Национальный технический университет "Харьковский политехнический институт", ул. Кирпичова, 2, 61108 Харьков, Украина

${ }^{3}$ Сулский государственный университет, ул. Рилского-Корсакова, 2, 40007 Сульь, Украина

${ }^{4}$ Национальный научный иентр "Харьковский фбизико-технический институт", ул. Акаделическал, 1, 61000 Харьков, Украина

5 Белгородский национальный исследовательский университет, ул. Победы, 85, 308015 Белгород, Россия

${ }^{6}$ Харьковский национальный автодорожный университет, ул. Я. Мудрого, 25, 61200 Харьков, Украина

Проанализировано влияние условий осаждения на структурно-фразовое состояние и термическую стабильность вакуумно-дуговых покрытий на основе слоев Ti(Al):Si. Исследованы однофразные однослойные покрытия, а также многопериодные бислойные покрытия с прослойками второй фразы из нитрида одного из трех металлов - Mo, Cr, Zr. Установлено, что в покрытии могут формироваться решетки гексагонального и кубического типов, причем переход к кубической решетке происходит при содержании $\mathrm{Al}$ около 25 ат. \%. Наличие в бислойных многопериодных композициях вторых нанораз мерных (7-8 нм) слоев, состоящих из одного нитрида из группы $\mathrm{CrN}_{x}, \mathrm{MoN}_{x}$ или $\mathrm{ZrN}_{x}$, не изменяет тип решетки в слоях [Ti(Al): $\mathrm{Si}] \mathrm{N}_{x}$. В слоях $\mathrm{CrN}_{x}$ и $\mathrm{ZrN}_{x}$ также фрормируется ГЦК решетка с сильно- или слабовыраженной текстурой [111], а в слоях MoN-кристаллиты с решеткой гексагонального типа. Высокотемпературный отжиг при температуре $700{ }^{\circ} \mathrm{C}$ в течение 40 минут приводит к значительному (на $23 \%$ или до $H_{\mu}=47,56$ ГПа) повышению микротвердости покрытия системы [ $\left.\mathrm{Ti}(\mathrm{Al})\right] \mathrm{N}_{x} / \mathrm{ZrN}_{y}$ вследствие формирования наноразмерной структуры со средним размером кристаллитов в [Ti(Al)] $\mathrm{N}_{x}$ слоях 3,8 нм, а в $\mathrm{ZrN}_{x}$ слоях - 6,3 нм.

Ключевые слова: Нитридные покрытия, Многослойное покрытие, Элементный состав, Структура, Микротвердость. 


\title{
Структура і властивості вакуумно-дугових одношарових і багатоперіодних двошарових нітридних покриттів на основі шарів $\mathrm{Ti}(\mathrm{Al}): \mathrm{Si}$
}

В.М. Береснев ${ }^{1}$, О.В. Соболь 2 , О.Д. Погребняк ${ }^{3}$, С.В. Литовченко ${ }^{1}$, В.А. Столбовой ${ }^{4}$, П.А. Сребнюк ${ }^{1}$, В.Ю. Новіков ${ }^{5}$ І І.В. Дощечкіна 6 , А.А. Мейлехов 2 , А.А. Постельник ${ }^{2}$, У.С. Немченко Б.А. Мазилін ${ }^{1}$, В.В. Круглова ${ }^{1}$

1 Харківський національний університет ілені В.Н. Каразіна, пл. Свободи, 4, 610о0 Харків, Україна

${ }^{2}$ Національний технічний університет "Харківський політехнічний інститут", вул. Кирпичова, 2, 61000 Харків, Україна

${ }^{3}$ Сулський державний університет, вул. Рилського-Корсакова, 2, 40007 Сули, Україна

${ }^{4}$ Національний науковий центр "Харківський фбізико-технічний інститут", вул. Академічна, 1, 61108 Харків, Украӥна

5 Белгородський національний дослідницький університет, вул. Перелоги, 85, 308015 Белгород, Росія

6 Харківський національний автодорожній університет, вул. Я. Мудрого, 25, 61200 Харків, Україна

\begin{abstract}
Проанализізовано вплив умов осадження на структурно-фазовий стан і термічну стабільність вакуумно-дугових покриттів на основі шарів $\mathrm{Ti}(\mathrm{Al}): \mathrm{Si}$. Було досліджено однофазні одношарові покриття, а також багатоперіодні бішарові покриття з прошарками другої фази з нітриду одного з трьох металів - Mo, Cr, Zr. Було виявлено, що в покритті можуть формуватися гратки гексагонального і кубічного типів, причому перехід до кубічної гратки відбувається при вмісті $\mathrm{Al}$ близько 25 ат. \%. Наявність у бішарових багатоперіодних композиціях других нанорозмірних (7-8 нм) шарів, що складаються з одного нітрида з групи $\mathrm{CrN}_{x}, \mathrm{MoN}_{x}$ або $\mathrm{ZrN}_{x}$, не змінюе тип гратки в [Ti(Al):Si] $\mathrm{N}_{x}$ шарах. У шарах $\mathrm{CrN}_{x}$ i $\mathrm{ZrN}_{x}$ також формується ГЦК гратка з сильно або слабовираженою текстурою [111], а в шарах $\mathrm{MoN}_{x}-$ кристаліти з граткою гексагонального типу. Високотемпературний відпал при температурі $700{ }^{\circ} \mathrm{C}$ протягом 40 хвилин призводить до значного (на $23 \%$ або до $H_{\mu}=47,56$ ГПа) підвищення мікротвердості покриття системи [Ti(Al)] $\mathrm{N}_{x} / \mathrm{ZrN}_{y}$ внаслідок формування нанорозмірної структури з середнім розміром кристалітів у [Ti(Al)] $\mathrm{N}_{x}$ шарах 3,8 нм, а в $\mathrm{ZrN}$ шарах $-6,3$ нм.
\end{abstract}

Ключові слова: Нітридні покриття, Багатошарові покриття, Елементній склад, Структура, Мікротвердість.

\section{REFERENCES}

1. R.F. Zhang, S Veprek, Mater. Sci. Eng. A 448, 111 (2007)

2. U.S. Nyemchenko, V.Yu. Novikov, S.S. Grankin, V.V. Ganenko, M.Yu. Arseenko, O.V. Sobol, O.P. Tkach, M.G. Kovaleva, L.V. Malikov, J. Nano- Electron. Phys. 7(2), 02040 (2015).

3. O.V. Sobol', Phys. Solid State 49(6), 1161 (2007).

4. O. Knotek, M. Bohmer, T. Leyendecker, Vac. Sci. Tech. A 4, 26950 (1986).

5. H. A. Jehn, S. Hofmann, V. E. Ruckbom, W. D. Munz, Vac. Sci. Technol. A 4, 2701 (1986).

6. C. Tritremmel, R. Daniel, M. Lechthaler, P. Polcik, C. Mitterer, Thin Solid Films 534, 403 (2013).

7. M. Uchida, N. Nihira, A. Mitsuob, K. Toyoda, K. Kubota, T. Aizawa, Surf. Coat. Tech. 177-178, 627 (2004).

8. J.L. Endrino, S. Palacín, M.H. Aguirre, A. Gutiérrez, F. Schäfers, Acta Materialia 55(6), 2129 (2007).
9. J. Patscheider, T. Zehndera, M. Diserens, Surf. Coat. Tech. 146-147, 201 (2001).

10. S. Veprek, S. Reiprich, Thin Solid Films 368, 64 (1995).

11. Ph.V. Kiryukhantsev-Korneev, D.V. Stansky, M.I. Petrznik, E.A. Levashov, B.N. Mavrin, Surf. Coat. Tech. 201, 6143 (2007).

12. P.H. Mayrhofer, A. Horling, L. Karlsson, J. Sjolen, T. Larsson, C. Mitterer, L. Hultman, Appl. Phys. Lett. 83, 2049 (2003).

13. O.V. Sobol', A.A. Andreev, S.N. Grigoriev, V.F. Gorban', S.N. Volosova, S.V. Aleshin, V.A. Stolbovoy, Probl. At. Sci. Tech. 4, 174 (2011).

14. A.A. Andreev, L.P. Sablev, S.N. Grigoriev, Vacuum-arc coatings (Kharkov: NSC KIPT: 2010).

15. Cavaleiro, Albano, De Hosson, Jeff Th. M., Nanostructured coatings (Springer-Verlag: 2006). 